\title{
On the Relationship of Ian Barbour's and Roy Bhaskar's Critical Realism
}

\section{By Andreas Losch}

"Critical Realism” is to some extent an equivocal term, although its ambiguity has rarely been noticed. The reason for this ambiguity is that the term has constantly been reinvented (Losch 2009, 98). Its use in a distinct area of research therefore shows much of the scope of the respective field of research. For instance, Ian Barbour coined the term "Critical Realism" in the context of the science and religion debate in 1966 as opposed to "naïve realism”, without noticing earlier uses of the term by Roy Wood Sellars, Dawes Hicks (1938), Bernard Lonergan (1957, 1961, 1972) or the early German critical realists. Critical Realism as a term was also applied on Roy Bhaskar's philosophy ${ }^{1}$, initially without recognition of its comparably earlier use in the science and religion debate (and also without being aware of the other uses of the term mentioned above). Nevertheless, the identity of the label and many family resemblances in content allowed for a transfer of thought between these different, although similar concepts, bearing the same name. The purpose of this article is to highlight the similarities and differences between the Barbour family of critical realism in science and religion and Roy Bhaskar's understanding of critical realism, and also to show the existing connections between both approaches. In a Bhaskarian context like this journal, it is therefore important to recall the features of the Barbour family of critical realism. Hence, we will start with their portrayal.

\section{The Barbour family of critical realism}

The presentation here can only be very brief and hence has to focus on the utmost essentials. The Barbour family of critical realism has been the dominant epistemology in the (Anglo-American) science-theology debate for several decades (van Kooten Niekerk 1998, 52). Its main proponents have been the three "scientist-theologians" (Polkinghorne 1996) Ian Barbour, Arthur Peacocke, and John Polkinghorne, of which only John Polkinghorne is still alive. Nevertheless, and despite being written off in some circles, critical realism in science and religion lingers on, as Ian G. Barbour-chair Robert John Russell elaborates (2004). The theologies of the three scientisttheologians are quite divergent, ranging from sort of a process theology (Barbour), to an emphasis on panentheism (Peacocke), on to a relatively orthodox approach (Polkinghorne). It would exceed the scope of this paper, however, to portray their theologies more detailed and we will focus on their reception of critical realism only.

First of these scientist-theologians was of course Ian Barbour, who advocated a sort of critical realism already in a 1966 paper in the newly established science and religion Journal Zygon ${ }^{2}$. There he portraits what he understands as "critical realism", that is an intermediate position avoiding positivism, instrumentalism, and idealism (Barbour 1966a, 29):

Avoiding these extremes, I would tend to end up where Northrop does with a kind of critical realism that says, 'Yes, science is trying to describe reality, but it does so only 
very indirectly in highly symbolic and abstractive language.' One has to use models, but one has to recognize their limitations; one has to realize that they are partial and limited, that each one selects certain aspects and emphasizes those that none of them corresponds exactly in any simple way to reality. (Barbour 1966a, 30)

Hence, the understanding of the use of models — which must be taken seriously but not literallylies at the heart of Barbour's critical realism, a fact which becomes most evident in his later monograph on Myths, Models and Paradigms (1974).

After formulating the idea in Zygon, Barbour applied the use of the concept on his Issues in Science and Religion. Here, Barbour defines critical realism as that it "must acknowledge both the creativity of man's mind, and the existence of patterns in events that are not created by man's mind. Critical realism acknowledges the indirectness of reference and the realistic intent of language as used in the scientific community.”(1966b, 172) The parlor of "patterns in events” points towards Barbour's patron for critical realism, which is Alfred North Whitehead. Barbour attributes his core claim of critical realism to this philosopher: "Whitehead speaks of 'a consciousness of ourselves as arising out of rapport, interconnection and participation in processes reaching beyond ourselves." (Barbour 1966b, 171) ${ }^{3}$ It has to be noted that this is a more far-reaching claim than the more formal definition of critical realism mentioned before.

It has not been a single source Barbour used when introducing critical realism coupled to Whitehead, but a field of scholars like Northrop and Hesse, who pointed in this direction when arguing on the downfall of naïve realism while holding to a realist approach. In his contribution to the Barbour Festschrift, Niels H. Gregersen further elucidates the sources of Barbour's interpretation of critical realism by mentioning a trend in the sixties that leads to a revival of scientific realism.

Our second critical realist scientist-theologian, Arthur Peacocke, picked the term up from Barbour, replacing his own formulation of a "skeptical and qualified realism” with it. "Skeptical and qualified" or critical realism means in Peacocke's portrayal that "models and hypotheses are regarded as 'candidates for reality', that is, models of, hypotheses about, a real (but only imperfectly known) world to which the models approximate and the hypotheses genuinely refer." (Peacocke 1979, 21) While the idea of critical realism in Peacocke's works is developed relatively independently - and, even more than in Barbour's case, in connection with the newer philosophical debate on scientific realism ${ }^{4}-$, the term itself is borrowed from Ian Barbour's influential work.

Finally, there is John Polkinghorne, who in his fundamental book named One World defends a view of science, which asserts its achievements to be a "tightening grasp of an actual reality." This is clearly an option for (convergent) realism. In his explicit interpretation, critical realism means, that all that can be achieved in the scientific process will be verisimilitude, not truth - "an adequate account of a circumscribed physical domain, a map good enough for some, but not for all, purposes.”(Polkinghorne 1987, 22) In contrast to Barbour, Polkinghorne portrays models as 
“valuable but of recognized inadequacy" $(1991,23)$; what for him is really desired is a single theory, which is - instead of models - his candidate for the verisimilitudinous description of physical reality $(1991,23)$. The term “critical realism” itself and its distinction from naïve realism may again stem from Barbour, which Polkinghorne marks as one of the major sources of his own work (Polkinghorne 1987, 99). Michael Polanyi and Thomas F. Torrance will have had an impact as well, and we will come back to that. In a later work, Polkinghorne refers to Peacocke's Intimations of Reality and Bernard Lonergan as well (1991).

Special to Polkinghorne's understanding of critical realism is a certain motto that evolves to describe it: "epistemology models ontology," $(1994,156)$ which means that the totality of what we can know is a reliable guide to what is the case. Polkinghorne's paradigm for this motto is the uncertainty relation (2000, 955). Originally, its understanding was epistemological in character; Heisenberg showed there were intrinsic limitations on what could be measured. Very shortly, Heisenberg and almost all other physicists were giving the principle an ontological interpretation. “It was treated as a principle of actual indeterminacy, not mere ignorance.” (Polkinghorne 1995, 148)

Barbour possibly influences also this train of Polkinghorne's thought. According to Barbour, it was Heisenberg's interpretation (endorsed by many physicists) that “indeterminacy is an objective feature of nature," and not only an epistemological limitation of man's knowledge. Barbour continues: "Such a viewpoint would accord with the critical realism we have advocated.” (Barbour 1966b, 303) Hence, hallmark of "the real” is not the observable any more, but the intelligible (1966b, 170).

Finally, also another ontological claim, the assumption of a stratified reality, is part of the Barbour family's interpretation of the term:

Critical realism makes the additional assumption that 'levels of analysis' reflect 'levels of organization' in the world. 'Level' is here intended to refer objectively to nature, that is, to a 'level of being'; it is a metaphysical and not simply a methodological concept... A level, like an arbitrary portion of a continuous spectrum, has no sharp boundaries; there are no separate strata marked off in nature. To the critical realist, the concept of levels is indeed an abstraction, and is relative to the context of inquiry, but it reflects in a limited and partial fashion the real structure of the world. (Barbour 1966b, 336)

A while after his Issues, Barbour gives a source for the concept, which is the philosopher William Wimsatt (Barbour 1997, 233). Still, this source cannot have been the source of the idea in the Issues, as Wimsatt's given writings are later than the publication of the Issues (Barbour 1997, 349). More likely, it has been process philosophy that inspired Barbour's concept of a metaphysical multiplicity of levels (Barbour 1966b, 336-37). When Barbour later states the need to modify the Whiteheadian system in this direction $(1997,290)$, this may be taken as a hint that the idea of a multiplicity of levels has been taken from another process philosopher, viz. Charles Hartshorne (Barbour 1966b, 334 and explicitly Barbour 2002, 33). Maybe there is also an 
influence of Michael Polanyi (Cf. Polanyi 1958, 381 and Polanyi 1983, 33-35), but probably not as strong as in Peacocke's case, for whom Polanyi does present a basis for much of his arguments: "Michael Polanyi's analyses of the hierarchical character of natural systems ... is the basis of the argument of this appendix and of much else in the rest of this volume." (Peacocke 1979, 371)

Also Polkinghorne advocated a "hierarchy, corresponding to the complexity of the systems treated” (Polkinghorne 1987, 86). This could have been based on Bohr’s complementarity principle, which Bohr himself suggested that it might prove of wider applicability. "In particular, he proposed that there might be a complementarity between life and atomic physics. Certainly if I break up a living creature into its constituent parts I kill it.” (Polkinghorne 1987, 89)

Polkinghorne, however, does not emphasize the importance of the complementarity principle, but adds the comment: “The deficiency in Bohr's suggestion is that it is really little more than a rephrasing of the last sentence.” $(1987,89)$ This may again be influenced by Barbour, who is critical of the concept of complementarity as well (Barbour 1974, 71-91).

\section{Barbour's critical realism: A bridge between science and religion}

A specialty of critical realism in the science and theology debate is that it is applied to theology as well, so "religious CR actually precedes secular [Bhaskarian] CR by nearly a decade" (Porpora 2005, 158). This application to theology may be related to the assumption of a layered hierarchy in nature so that theology can potentially be reinstated as the queen of sciences. In any case, the beginnings of this important step again reach back to Barbour, who quotes - among others - A.N. Whitehead to make the bridging claim:

"The dogmas of religion are the attempts to formulate in precise terms the truths disclosed in the religious experience of mankind. In exactly the same way the dogmas of physical science are the attempts to formulate in precise terms the truths disclosed in the senseperception of mankind.” (Whitehead 1960, 57, quoted in Barbour 1966b, 129)

Polkinghorne follows Barbour in quoting this paragraph (Polkinghorne 1987, 28) and combines this quote of Whitehead with the Anselmian idea that theology is fides quaerens intellectum. Peacocke, however, does not use Whitehead, yet nevertheless expresses his agreement with Barbour when he states: "In a not dissimilar manner [as in science], Christians, indeed all religious believers, also regard themselves as making meaningful assertions about a reality which man can and does encounter." (Peacocke 1979, 22) Hence, critical realism is always portrayed as one of the similarities between science and religion: "The interpretive language of both communities is used realistically and referentially.” (Barbour 1966b, 267)

Among the parallels that Barbour observes between science and religion is (1) the fact that in both cases there is no uninterpreted experience; further, (2) the significance of the community and its paradigms; and finally, (3) the use of models and analogies in both science and religion. In his summary of the comparison of the methods of science and religion, Barbour lists a further 
similarity: (4) interconnected networks of concepts are evaluated together, using simultaneous criteria of coherence, comprehensiveness, and adequacy to experience.

Barbour also has a list of differences between science and religion, but for the sake of brevity we will focus here on the bold claim of similarities between the two fields. Barbour's point of view culminates in the statement that although "the contrasts of science and religion must always be kept in mind," these "contrasts are not as absolute as most recent theologians and philosophers have maintained.” (Barbour 1966b, 268)

As Barbour is the one of the three scientist-theologians who has dealt most extensively with the social and human sciences, we restrict ourselves in these regards to portraying his view of the role of these sciences in critical realism. To be sure, Barbour defined critical realism already while dealing exclusively with natural science (1966b, 172), but its application on religion to some extent rests on the results he achieved when comparing natural, social and human sciences. These results are that "instead of a sharp dichotomy, we have rather a spectrum with varying degrees and types of personal involvement, and varying types of interest in the lawfulness and uniqueness which are characteristics shared by all events.” (Barbour 1966b, 176) We will refer to this as Barbour's "spectrum thesis". 5

Peacocke agrees with the viability of critical realism for models in theology, "whereby theological concepts and models are partial and inadequate, but necessary and, indeed, the only ways of referring to the reality that is God and God's relation to humanity.” (Peacocke 1984, 40) That a critical (or skeptical and qualified) realism is appropriate in both domains is the first similarity between theological and scientific models he lists $(1984,41)$, and we may add to that the aspect that they "reflect reality and are to be taken seriously but not literally." (Peacocke 1984, 42) An interesting further similarity he gives is that models in both disciplines are concerned less with picturing objects than with depicting patterns of relationships (Peacocke 1984, 42). Finally, Peacocke also lists the importance of the role of the community as a "living tradition of reference” for models in science and religion (1984, 42). Already earlier, Peacocke subscribed to the idea of the parallel search for intelligibility in both science and theology (1981, xii).

Polkinghorne discusses six parallels between critical realism in science and theology. What is firstly valid in both domains is "charity of reference" that "we must resist 'total account' theories of knowledge and be prepared instead to value more piecemeal achievements.” $(1998,105)$ Nevertheless, he is aware of the fact that the conflicting variety of world faith traditions presents the most severe challenge to theological realism $(1998,113)$. His second point is, going along with Michael Polanyi, that science is an activity of persons, drawing on tacit skills learned through apprenticeship in a community $(1998,106)$, and hence the difference between science and theology "is not of a fundamental kind but it lies in the degree of power of empirical interrogation which these various investigations enjoy.” $(1998,114)$ Already Barbour used Polanyi for making this point (Losch 2010, 409). Third, as there are no significant scientific facts that are not already interpreted facts (Polkinghorne 1998, 107) and there therefore is an inescapable, though benign, circularity of science, theology likewise "has long known that one 
must believe in order to understand ... and yet also one must understand in order to believe.” (Polkinghorne 1998, 115) We may account this aspect to the influence of Michael Polanyi, too (See Losch 2005, 277). Fourth, as quantum physics has shown that there is no universal epistemology and that our knowledge of entities must conform to their idiosyncratic natures (Polkinghorne 1998, 108), Thomas Torrance has emphasized that God is also to be known in ways that conform to the divine nature (Polkinghorne 1998, 116). Fifth, as social factors can accelerate or inhibit the growth of scientific knowledge, but do not determine the character of that knowledge (Polkinghorne 1998, 108), theology is not a purely social construction. The insights Polkinghorne wins by a (revised) natural theology that draws on the intelligibility and fruitfulness of the universe and so looks outside the realm of existential human experience, endorse this perspective (1998, 121). Sixth, and most important to Polkinghorne, scientific realism has been formulated as the best means of understanding the actual experience of doing science. At its heart lies the conviction that intelligibility is the reliable guide to ontology $(1998,108)$. The fact, that we are people of such an intellectual kind, living in a universe of such rationally transparent kind, that we are able to understand a great deal of the pattern and process of the world that we inhabit, this very possibility of science is theologically to be understood as the consequence of the deposit of the imago dei within humanity $(1998,122){ }^{6}$

Finally, there is Wentzel Van Huyssteen, a theologian, who entered the critical realism debate late and also withdrew to some extent a while ago (See van Huyssteen 1999, 213-21). He at least has to be mentioned here, because he has been well received by one of the first "Bhaskarians" taking note of the Barbour family of critical realism, Brad Shipway (2000). Also John Polkinghorne refers to van Huyssteen shortly (Polkinghorne 1998, 123-24).

\section{Similarities and differences between Barbour's and Bhaskar's approaches}

After this exposition of the Barbour family of critical realism, it is time to highlight similarities and differences to Roy Bhaskar's philosophy.

According to the authors of transcendence, Bhaskar's critical realism "stands midway between a positivism ... and a more current postmodernism.” (Archer, Collier, and Porpora 2004, 1) In this characteristic it meets with Barbour's attempt of an intermediate position avoiding positivism, instrumentalism, and idealism. Moreover, this seems to be a basic feature shared between all sorts of critical realism (Losch 2009, 98).

Similar between the approaches mentioned is also the understanding of reality dealt with. We do not talk about the medieval distinction between realism and nominalism here, aimed at the question of the existence of universals ${ }^{7}$. Our realism in both cases is realism after Kant, directed at the "question of the existence of the tempo spatial world and to the question of the relation between phenomena and being” (Losch 2009, 86).

Both critical realisms also share the view of a stratified reality, presumably mediated not only through the ancient idea of a scala naturae (Lovejoy 1936), but also through the thought of Michael Polanyi. In Ian Barbour's case the influence by process philosophy in its Hartshornian 
interpretation may have been stronger than the influence by Polanyi, while Bhaskar explicitly recognizes Polanyi's impact in these regards ${ }^{8}$.

Another common issue of critical realisms may be a relation to the evolving scientific method (Losch 2009, 98). Ian Barbour has a take on science that is in some regards already

hermeneutically conceived, so he ends up with his spectrum thesis embracing science, humanities and religion under one umbrella, differing only in relative objectivity/subjectivity, while Roy Bhaskar more explicitly sticks to the hermeneutical tradition's inherent differentiation between science and humanities, although his critical naturalism, too, "may be defined as the thesis that there is an essential unity of method between the natural and the social sciences." (Bhaskar 1979, 3) The occupation with the question of hermeneutics is therefore both a similarity and, regarding its further development, also a difference between Barbour’s and Bhaskar’s approaches.

To this may be added the difference, that Bhaskar is willing to essentially differentiate the rationalities of the sciences (and of humanities), while Barbour emphasizes more the rational similarity of both approaches, which could justifiably be called an apologetic move (Gironi 2012, 42). As mentioned before, Ian Barbour's ideas are much informed by Alfred North Whitehead's ideas $^{9}$, while this is not the case with Roy Bhaskar's critical realism, who - to my knowledge - is orientated at Marx and does not refer to Whitehead at all. Polkinghorne, again, is only partially influenced by Whitehead (Losch 2005), and more by Michael Polanyi, whom also Peacocke embraces.

A fundamental difference between the Barbour family of critical realism and Roy Bhaskar's approach is also the origin of the term itself. While in Barbour's and many other critical realisms' case, the attribution "critical" serves to distinguish the epistemological stance taken from an assumed "naïve" approach to reality, the term has been used on Roy Bhaskar's philosophy as a merger of his two basic assumptions of a critical naturalism and a transcendental realism. Bhaskar is therefore somewhat free of the shortcomings of Barbour's coining of the term, where the attribution "naïve" "always carries a kind of suggested inferiority, which is due to the conviction of those who use this term on others to regard their own point of view as a more sophisticated and developed stance” (Losch 2009, 88). One can assume that Barbour himself became aware of this problem and hence started to label "naïve" realism more positively as “classical” realism instead (Losch 2009, 88).

This list of similarities and differences between Barbour's and Bhaskar's approaches may not be exhaustive, although it provides a good start for further research, I believe.

\section{Connections between the two approaches}

The first early uses of Bhaskar's critical realism on behalf of proponents of the Barbour family of critical realism have been performed by Janet Martin Soskice (1987, 120-23), ${ }^{10}$ whose concept of metaphors and models has been influential on Peacocke's Intimations of Reality (Peacocke 1984, 
85). In the context given, Soskice speaks of the "rise of critical (as opposed to naïve) realism in the philosophy of science" (Soskice 1987, 120) and later on uses Bhaskar's Realist Theory of Science (Bhaskar 2008). ${ }^{11}$

The idea to integrate Bhaskar's account of critical realism into the science and religion debate has also been brought forward by Wentzel van Huyssteen. He only mentioned it shortly, however (van Huyssteen 1989, 155). From the side of the Bhaskarians, Brad Shipway wrote an early article on "Critical Realism and Theological Critical Realism. Opportunities for Dialogue?" (Shipway 2000), an elaboration of a conference paper by Douglas Porpora ${ }^{12}$. There Shipway presents the Barbour family of critical realism, although largely based on the argument of Wentzel van Huyssteen (van Huyssteen 1998; 1999), and only to some extent based on the works of John Polkinghorne (Polkinghorne 1998) and of Alister McGrath (McGrath 1998, 1999). As a view from outside of the Barbour family of critical realism, Shipway's view, unfortunately, is not always accurate. One topic he identifies as essential in the Barbour family is the principle of complementarity (Shipway 2000, 32). As indicated before, this is for sure a core topic in the science and religion discourse, it is just inappropriate to connect it with the idea of critical realism. Let me explain. Ian Barbour is famous for his fourfold typology of potential relationships between science and religion, which range from conflict to independence, dialog and even integration. This typology has been fully developed in his Gifford Lectures (Barbour 1990, 3-30), and their extension Religion and Science (Barbour 1997, 77-105) and later even been applied to classify the whole emerging field of science and religion (Barbour 2000). Important roots of this typology have been present in his 1966 Issues in Science and Religion already, and actually his whole idea of critical realism is an effort to overcome the that time prevalent independence model of science and religion in academia; and complementarity is an exemplary idea for that independence view of science and religion, so something Barbour's critical realism just wants to overcome ${ }^{13}$.

Shipway is of course right that Bhaskar's and Barbour's critical realism display "not a few congruencies” (Shipway 2000, 32), and it is their significance that should be debated. One should nevertheless take care not to label everything written by the relevant science and religion authors as critical realism; this is only one - although central - part in their theologies, while with Bhaskar it is a name for his whole philosophical system ${ }^{14}$.

The overall situation somewhat changed with the arrival of Alister E. McGrath's three volume work A Scientific Theology, where he - a "next-generation” scientist-theologian- engages directly with the critical realism of Bhaskar (Shipway 2004a, 191). One should, however, note that McGrath entered the science and religion debate comparatively late, and his critique of Barbour's critical realism has somewhat been regarded as that of an outsider's view. I assume this has been subject to change, but it should be noted. McGrath dealt with critical realism earlier, though in a rather broad way, which shows, however, more a wide range of scholarship than a focus on the traditional Barbourian science and religion field. Also, the way McGrath was blaming the previous critical realism discourse in science and religion for ignoring Bhaskar was certainly not justified, as the application of the term “critical realism” on Bhaskar's philosophy 
has been much more recent than the coining of the term in the science and religion debate ${ }^{15}$. Nevertheless, it was, of course, due time to get the two siblings of critical realism into a relation, which is McGrath's huge merit in the debate.

McGrath reports that his encounter of Roy Bhaskar's philosophy in 1998 was a breakthrough for him, as he finally "had found a form of critical realism that took the social location of the observer seriously” (McGrath 2006, xvi). This is not the place to present McGrath's thoughts in depth $^{16}$. However, the features of critical realism McGrath highlights should be mentioned, as McGrath in person represents a bridge between the Barbour family tradition of critical realism and the Bhaskarian version of it. A crucial feature of McGrath's critical realism, however, is a combination of the spectrum thesis with a conviction of the stratification of reality (McGrath 2006, 12). This could certainly be stated about the Barbour family as well ${ }^{17}$. McGrath, however, additionally elaborates the very Bhaskarian feature of an a posteriori working methodology of each science, appropriate to the ontology of its particular object of investigation. "The stratification of reality demands different working methods and assumptions across the spectrum of the sciences, despite the critical commonalities that may be identified.” (McGrath 2006, 12)

\section{Conclusion and Outlook}

McGrath's modification resonates very well with my own early thoughts and critiques of the plain Barbour family critical realism ${ }^{18}$. When McGrath states, that "by virtue of their subject matters, a higher degree of constructivism is implicit in psychology or the social sciences than in biology or physics", a very similar thought lead me to propose a modification of the Barbour family critical realism to what I called a “constructive-critical realism”. This way, I also try to explore Michael Polanyi’s differentiation between verification taking place in science, and validation as equivalent activity in mathematics, arts, and religion (Polanyi 1958, 202). By the application of the double adjective 'constructive-critical' on realism, I, therefore, want to remember Polanyi’s interpretation of Dilthey’s historical insight on differences between natural and human science. "For the science of the impersonal, a mostly critical view of the personal involvement in the process of science may justifiably dominate, because according to intersubjective agreement and commitment, the object of study is the impersonal world. However, in the science of the personal, the degree of personal involvement is too deep to call it simply a 'critical' element. Already the 'subjective' character of the object of enquiry demands a higher estimation of the subject in the process of knowledge. Hence, the sciences of the personal cannot simply claim objective reality to major on the subjective element within the process of science, as plain critical realism does. When science becomes an interpersonal inquiry, the process of knowledge is recursive in a higher degree.” (Losch 2005, 282)

I elaborated in these lines a train of thought present in the works of John Polkinghorne, who postulates (as has been noted) the slogan “epistemology models ontology” as most appropriate expression of critical realism. Polkinghorne is well aware of this distinction of methodologies 
according to the different objects researched, an idea much stressed by Thomas F. Torrance (Torrance 1969, 9), and even labels the insight that "components of reality ... are known in ways that accord with their natures" and that we cannot determine beforehand what these epistemological modes will be as "congenial to the scientific mind.” (Polkinghorne 1998, 81) 19 The rationalities applied in the sciences, the humanities and in theology are indeed as different as their subjects are divergent. When I discovered McGrath's reception of this Bhaskarian (as well as Barthian) thought (McGrath 2006, 217), I, of course, included it in my argument (Losch 2010, 409).

Later I added the common insight that the subject of theology - God - is indeed a subject and not an object. God is a personal counterpart (Losch 2014b, 160). This of course diverges from Roy Bhaskar's point of view in From East to West, where he elaborates his idea "that man is essentially God ...; and that, as such, he is essentially free and already en-lightened” (Bhaskar 2000, ix). I would concur with the idea that we are created in the image of God, and eventually may be called children (or even sons) of God. The formulation by Bhaskar himself is to my personal theological convictions lacking transcendence. Nevertheless, I can understand that it is an important challenge not only to incorporate critical realism in a scientific theology, yet also to deal with the more recent spiritual turn(s) in Bhaskar's philosophy (Archer, Collier, and Porpora 2004, 168). I only want to add one warning: the question if God exists is maybe a matter that needs theological reflection as well ${ }^{20}$.

\section{References}

Archer, Margaret S., Andrew Collier, and Douglas V. Porpora. 2004. Transcendence: Critical realism and God. Critical realism—interventions. London, New York: Routledge.

Barbour, Ian G. 1966a. "Commentary on Theological Resources from the Physical Sciences.” Zygon 1 (March): 27-30.

—. 1966b. Issues in Science and Religion. Englewood Cliffs, N.J: Prentice-Hall. 1974. Myths, Models and Paradigms: A Contemporary Study in Science \& Religion. New York: Harper \& Row.

. 1990. Religion in an Age of Science. $1^{\text {st }}$ ed. The Gifford lectures v. 1, 1989-1991 [i.e. 1990]. San Francisco: Harper \& Row.

1997. Religion and Science: Historical and Contemporary Issues. A rev. and expanded ed. of "Religion in an age of science”. San Francisco: Harper.

. 2000. When science meets religion. $1^{\text {st }}$ ed. [San Francisco]: HarperSanFrancisco.

—. 2002. Nature, human nature and God. Theology and the sciences. Minneapolis Minn. Fortress Press. 
Berg, Christian. 2002. Theologie im technologischen Zeitalter: Das Werk Ian Barbours als Beitrag zur Verhältnisbestimmung von Theologie zu Naturwissenschaft und Technik. Forum Systematik 18. Stuttgart: Kohlhammer.

Bhaskar, Roy. 1979. The Possibility of Naturalism: A Philosophical Critique of the Contemporary Human Sciences. Philosophy now. Brighton, Sussex: Harvester Press. 1989. Reclaiming Reality. London, New York: Verso. 2000. From East to West: Odyssey of a Soul. Critical realism-interventions series. London, New York: Routledge.

—. 2008. A realist theory of science. Radical thinkers 29. London, New York: Verso.

Buitendag, Johan. 2012. "Epistemology, Ontology and Reciprocity: Bringing Bram Van De Beek in Dialogue with John Polkinghorne.” In Strangers and Pilgrims on Earth: Essays in Honour of Abraham Van De Beek, edited by Abraham van de Beek, Eduardus A. J. G. van der Borght, and Paul van Geest, 779-95. Studies in Reformed theology v. 22. Leiden, Boston: Brill.

Gironi, Fabio. 2012. “The Theological Hijacking of Realism.” Journal of Critical Realism 11 (1): 40-75. doi:10.1558/jcr.v11i1.40.

Hicks, G. D. 1938. Critical Realism: Studies in the Philosophy of Mind and Nature. London: Macmillan.

Lonergan, Bernard J. F. 1957. Insight: A Study of Human Understanding. London: Longmans Green \& Co.

-1961. Critical Realism and the Integration of the Sciences.

—. 1972. Method in Theology. London: Darton, Longman and Todd.

Losch, Andreas. 2005. "Our World Is More Than Physics: A Constructive - Critical Comment on the Current Science and Theology Debate.” Theology and Science 3 (3): 275-90. doi:10.1080/14746700500317271.

—. 2009. “On the Origins of Critical Realism.” Theology and Science 7 (1): 85-106. doi:10.1080/14746700802617105.

. 2010. “Critical Realism-A Sustainable Bridge Between Science and Religion?” Theology and Science 8 (4): 393-416. doi:10.1080/14746700.2010.517638.

—. 2014a. “Glauben als Grundlage: Michael Polanyis Berufung auf die Bedeutung des Glaubens in der Wissenschaft und die Rezeption seiner Philosophie im Gespräch von Theologie und Naturwissenschaften.” In Jenseits der Sprache: Interdisziplinäre Beiträge zur Wissenstheorie Michael Polanyis, edited by Eva-Maria Jung, 107-36. Münster, Westf: mentis.

_. 2014b. "Wissenschaftliche und religiöse Welterfassung. Ein Kommentar zu Martin Bubers Perspektive auf ein spannungsreiches Thema.” Theologische Zeitschrift 70 (2): 142-61. 
Lovejoy, Arthur O. 1936. The Great Chain of Being: A Study of the History of an Idea. Cambridge Mass. Harvard Univ. Press.

Martin, Janet, and Ron Harré. 1982. "Metaphor in Science.” In Metaphor: Problems and Perspectives, edited by David S. Miall, 89-105. Brighton: Harvester Press.

McGrath, Alister E. 1998. The Foundations of Dialogue in Science and Religion. Malden, Mass. Blackwell Publishers.

. 1999. Science and religion: An introduction. 1. publ. [erschienen 1998]. Oxford u.a. Blackwell.

. 2006. A Scientific Theology. T \& T Clark theology. London, New York: T \& T Clark.

Peacocke, A. R. 1979. Creation and the World of Science: The Bampton Lectures, 1978.

Bampton lectures 1978. Oxford: Clarendon Press.

. 1981. The Sciences and Theology in the Twentieth Century. Stocksfield [England]: Oriel Press.

1984. Intimations of Reality: Critical Realism in Science and Religion. The Mendenhall lectures 1983. Notre Dame, Ind. Published for DePauw University, Greencastle, Ind., by University of Notre Dame Press.

Polanyi, Michael. 1958. Personal Knowledge: Towards a Post-Critical Philosophy. Chicago: University of Chicago Press.

— 1983. The Tacit Dimension. Gloucester, Mass. Peter Smith.

Polkinghorne, J. C. 1979. The Particle Play. Oxford: Freeman.

- 1987. One World: The Interaction of Science and Theology. Princeton, N.J: Princeton Univ. Press.

1991. Reason and Reality: The Relationship Between Science and Theology. $1^{\text {st }}$ Trinity Press International ed. Philadelphia: Trinity Press International.

1994. Science and Christian Belief: Theological Reflections of a Bottom-up Thinker ; the Gifford Lectures for 1993-4. $2^{\text {nd }}$ impr. London: SPCK.

1995. "Metaphysics of Divine Action.” In Chaos and Complexity: Scientific

Perspectives on Divine Action, edited by Robert J. Russell, 147-56. Scientific perspectives on divine action 2. Vatican City State: Vatican Observatory Publ.

-1996. Scientists as Theologians: A Comparison of the Writings of Ian Barbour, Arthur Peacocke and John Polkinghorne. London: SPCK.

- 1998. Belief in God in an Age of Science. The Terry lectures. New Haven, CT: Yale University Press.

—. 2000. "The Life and Works of a Bottom-up Thinker.” Zygon 35 (4): 955-62.

doi:10.1111/1467-9744.00325. 
Porpora, Douglas V. 2005. “The Spiritual Turn in Critical Realism.” New Formations 15 (1): $147-61$.

Russell, Robert J. 2004. "Ian Barbour's Methodological Breakthrough: Creating the 'Bridge' Betweeen Science and Theology.” In Fifty Years in Science and Religion: Ian G. Barbour and His Legacy, edited by Robert J. Russell, 45-60. Ashgate science and religion series. Aldershot: Ashgate.

Shipway, Brad. 2000. "Critical Realism and Theological Critical Realism: Opportunities for Dialogue?” alethia 3 (2): 29-33.

— 2004a. "The Theological Application of Bhaskar's Stratified Reality.” Journal of Critical Realism 3 (1): 191-203.

_ 2004b. “The Theological Application of Bhaskar's Stratified Reality: The Scientific Theology of A.E. McGrath.” Journal of Critical Realism 3 (1): 191-203.

Soskice, Janet M. 1987. Metaphor and Religious Language. Oxford: Clarendon Press.

Torrance, Thomas F. 1969. Theological Science. London: Oxford University Press. van Huyssteen, J. W. 1989. Theology and Justification of Faith: Constructing Theories in Systematic Theology. Grand Rapids, Mich. Eerdman.

- 1998. Duet or Duel? Theology and Science in a Postmodern World; the 1998 Diocese of British Columbia John Albert Hall Lectures at the Centre for Studies in Religion and Society in the University of Victoria. John Albert Hall lectures. London: SCM.

1999. The Shaping of Rationality: Toward Interdisciplinarity in Theology and Science. Grand Rapids, Mich. Eerdmans.

van Kooten Niekerk, Kees. 1998. “A Critical Realist Perspective.” In Rethinking Theology and Science: Six Models for the Current Dialogue, edited by Niels H. Gregersen and Wentzel van J. Huyssteen, 51-86. Grand Rapids, Michigan, Cambridge, UK: Eerdmans.

Whitehead, Alfred N. 1960. Religion in the Making. 1. print. Living age books 28. New York NY: Meridian Books.

Andreas Losch is postdoc at the Center for Space and Habitability, University of Bern, and also afiliated with the faculty of theology there.

Email: andreas.losch@csh.unibe.ch

\footnotetext{
1 "I had called my general philosophy of science 'transcendental realism' and my special philosophy of the human sciences 'critical naturalism'. Gradually people started to elide the two und refer to the hybrid as 'critical realism'." (Bhaskar 1989, 190)

${ }^{2}$ Much of the following lines are taken from two previous articles on the subject matter, Losch 2009 and Losch 2010, both copyright (C) Center for Theology and the Natural Sciences the relevant parts reprinted by permission of (Taylor \& Francis Ltd, http://www.tandf.co.uk/journals) on behalf of Center for Theology and the Natural Sciences.

${ }^{3}$ The attribution to Whitehead is unfortunately wrong, cf. Losch 2009, 102.
} 
4 "Peacocke refers to other realist philosophers, Hilary W. Putnam in the beginning and later on also Ernan McMullin, W.H. Newton-Smith, Wilfrid Sellars, lan Hacking and J. Worrall". (Losch 2009, 90-91)

${ }^{5}$ Best expressed in this statement: "We find no ... sharp line that would justify the division of academia into two opposing camps, but rather a 'spectrum' within which the role of man's subjective life varies greatly." (Barbour 1966b, 188)

${ }^{6}$ We can observe here a reflection of Polkinghorne's original bridging idea; cf. (Polkinghorne 1979, 126).

${ }^{7}$ As noted, the critical realism of Bernard Lonergan is different in these regards.

${ }^{8} \mathrm{He}$ is anxious to mention Polanyi when referring to his own development of the theme, cf. Bhaskar 1989, 80. Compare also Bhaskar 2008, 111.

${ }^{9}$ It could well be, as Fabio Gironi puts it, that "here (and indeed in most ... attempts to build a 'process theology') Whitehead's 'God' is presented against Whitehead's own intentions." $(2012,49)$

${ }^{10}$ Already in a 1982 paper, Soskice (formerly only named "Martin") referred to "transcendental realism", yet without mentioning Bhaskar explicitly. (Martin and Harré 1982)

${ }^{11}$ However, her use of "critical realism" cannot stem from the source of Bhaskar, because in this book he advocates a position he does not call "critical", but "transcendental realism" (Bhaskar 2008, 15). The label "critical realism" was only later addressed to and used by Bhaskar.

${ }^{12}$ Now Published as Porpora 2005. Porpora was influenced by Barbour's critical realism even before encountering Bhaskar's works. (Porpora 2005, 156)

${ }^{13}$ While he embraced that concept once himself, by the way. (Berg 2002, 38-39).

${ }^{14}$ Besides the necessity of keeping this paper at a reasonable length, this evaluation is the reason why I mostly restricted myself to sketching the epistemological aspects of the Barbour family's critical realism.

${ }^{15}$ Hence also Gironi's move from this mistaken starting point does not make sense. (Gironi 2012, 57)

${ }^{16}$ For an analysis, see Shipway 2004b.

17 Potentially contrary to McGrath's own statement. (McGrath 2006, 219)

${ }^{18}$ See Losch 2005 and its discussion in Buitendag 2012.

${ }^{19}$ The quantum world does not follow Aristotle's logic, for instance.

${ }^{20}$ Paul Tillich made an important differentiation between God's essence and God's existence, and Polanyi picked this up his way, which may present a clue to some discussions around the correct interpretation of Polanyi's thought. (Losch 2014a, 125) 